\title{
Прогнозування ефективності неоад"ювантної таргетної терапії у хворих на локалізований нирково-клітинний рак
}

\author{
Національний інститут раку, Київ \\ Отримано 03.05.2019 \\ Прийнято до друку 27.05.2019 \\ DOI: $10.32471 /$ clinicaloncology.2663-466X.38.22480
}

\begin{abstract}
Мета - визначити прогностичні критерії ефективності проведення неоад'ювантної таргетної терапії (ТT) в лікуванні хворих на локалізований нирково-клітинний рак (НКР). Об'єкт і методи. 58 пацієнтів із локалізованим НКР, яким в період з 2017 по 2018 р. проведено 2 блоки неоад'ювантної ПТ з визначенням об'єктивної відповіді на лікування та подальшим оперативним втручанням. Результати. Частка регресії пухлини після проведення ТT - 20,5 14,3\% (95\% довірчий інтервал (ДІ) 16,8-24,3). Розмір НКР зменшився в середньому на 12,3 мм - $360,8 \pm 19,7$ мм (95\% ДІ 55,7-66) до 48,5 16,4 мм (95\% ДІ 44,2-52,8) (t-test; p<0,001), що дозволило в 53 випадках $(91,4 \%)$ провести резекцію нирки. За допомогою кореляційного аналізу Пірсона виявлено достовірну кореляційну пряму залежність $(r=0,77613 ; p<0,001)$ розміру НКР після проведення неоад'ювантної ТТ від розміру локалізованого НКР до її виконання. Констатовано відсутність залежності рівня об'єктивної відповіді пухлини на проведення неоад'ювантної ТТ від розміру локалізованого НКР. Висновки. Розроблено систему прогнозування рівня регресії локалізованого НКР внаслідок проведення неоад'ювантної ТТ, що дозволяє $395 \%$ вірогідністю визначити ефективність зменшення розмірів пухлини та доцільність такого лікування.
\end{abstract}

Ключові слова: нирково-клітинний рак; неоад'ювантна таргетна терапія.

\section{вступ}

На сьогодні рак нирки є однією з найбільш поширених онкологічних патологій. У 2012 р. в Європі зареєстровано 84400 випадків захворювання на нирково-клітинний рак (НКР) та 34700 випадків смерті від нього. Слід відмітити, що до $70 \%$ пацієнтів мають локалізовані форми НКР і підлягають лише оперативному лікуванню [1].

Лише 10 років тому золотим стандартом та єдиним методом лікування локалізованого НКР було проведення радикальної нефректомії [2], однак у подальших когортних дослідженнях, заснованих на обробці бази даних пацієнтів, що включала понад 1 млн хворих, було доведено, що нефректомія асоціюється з підвищеним ризиком подовження тривалості госпіталізації, зростання рівня серцево-судинних захворювань та навіть ризику смерті пацієнтів [3].

Внаслідок цього було переглянуто ставлення до органозберігаючої тактики лікування хворих на локалізований НКР, і резекція нирки стала операцією вибору [4, 5]. У подальшому iii онкологічна ефективність була доведена у численних клінічних дослідженнях з більшою тривалістю життя пацієнтів, мінімальною кількістю випадків хронічної ниркової недостатності та значно кращою якістю життя [6, 7]. Однак у більшості випадків при НКР розміром $>4$ см або при локалізації пухлини у воротах нирки проводиться нефректомія, а у публікаціях різних країн світу превалюють повідомлення про середній розмір резектованих пухлин у межах $2-3 \mathrm{~cm}$.

Однією з потенційних переваг передопераційної таргетної терапії (ТТ) є можливість зменшення розміру пухлини нирки і перетворення нерезектабельних пухлин на резектабельні. Існують нечисленні дослідження такого підходу в літературі на невеликих серіях, в яких відмічається значна неоднорідність аналізованих груп $[8,9]$. Проблема полягає у відсутності стандартизації визначення «резектабельності» пухлини в різних центрах, що залежить від різноманітних факторів, одним 3 яких є вміння і досвід хірурга, наявність багатопрофільної хірургічної команди [10]. Незважаючи на гетерогенні дані, початкові результати свідчать про те, що цей підхід може мати деякі переваги у пацієнтів з проміжними показаннями до резекції або нефректомії.
Враховуючи вищезазначене, з 2017 р. в науково-дослідному відділенні пластичної та реконструктивної онкоурології проводиться дослідження з вивчення ефективності неоад'ювантної ТТ в лікуванні локалізованого НКР.

Мета - визначити прогностичні критерії ефективності проведення неоад'ювантної ТТ в лікуванні хворих на локалізований НКР.

\section{КЛІНІЧНИЙ МАТЕРІАЛ}

Предметом вивчення стали 58 пацієнтів із локалізованим HKP (T1-T2N0M0), яким в період з 2017 по 2018 р. в науково-дослідному відділенні пластичної та реконструктивної онкоурології Національного інституту раку проведено 2 блоки неоад’ювантної ТТ препаратами першої лінії з подальшим оперативним лікуванням.

Показання до проведення неоад'ювантної ТТ були імперативними, що становить 19 (32,8\%) випадків, серед яких двобічний НКР діагностовано у 7 (24,1\%), НКР єдиної нирки $-5(8,6 \%)$ пацієнтів, та елективними - $39(67,2 \%)$ випадків, серед яких центральне розмішення НКР > 20 мм - 21 (36,2\%), периферичне або полярне розміщення НКР, що поширюється на нирковий синус при об'ємі функціонуючої паренхіми нирки $>50 \%,-18(31 \%)$.

TT проводили за стандартною схемою: пазопаніб 800 мг щоденно перорально протягом 2 міс; сунітиніб по 50 мг щоденно протягом 28 діб з перервою в прийомі препарату протягом 14 діб та повторним 28-денним курсом терапії.

Оцінку ефективності ТТ проводили на основі променевих методів візуалізації (ультразвукове дослідження, комп'ютерна та магнітно-резонансна томографія, урографія), які використовували як при первинному, так і при всіх контрольних обстеженнях. Ступінь регресії первинної пухлини визначали за критеріями оцінки відповіді солідних пухлин на терапію Response Evaluation Criteria in Solid Tumors (RECIST) [13] та відсотком регресії пухлини. Також було оцінено кількість проведених резекцій нирки та нефректомій.

Оперативне лікування проводили в термін $>2$ тиж після припинення або закінчення курсу неоад'ювантної ТТ з метою повного виведення таргетного препарату з організму задля 
кращої регенерації тканин після оперативного лікування. Перевага надавалася резекції нирки при обсязі збереженої функціонуючої паренхіми $>50 \%$ при технічних можливостях iї проведення за умови збереженого кровопостачання нирки та сечовідведення з неї.

Клінічна характеристика хворих: чоловіків - 39 (67,2\%), жінок - 19 (32,7\%). Вік пацієнтів коливався від 26 до 72 років і в середньому становив 55,3 $\pm 10,3$ року (95\% довірчий інтервал (ДІ) 52,6-58), ECOG статус 0 [0; 1] балів. Розміри пухлинного ураження становили від 16 до 113 мм, в середньому 60,7士19,8 мм (95\% ДІ 55,5-66). Загальна швидкість клубочкової фільтрації сягала 88,6 $\pm 26,1$ мл/хв/1,73 м² (95\% ДІ 76,7-

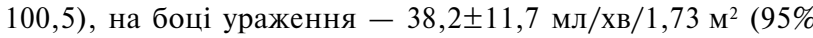
ДІ 26,7-42,5). Половина пацієнтів, а саме 29 (50\%), мали супутню патологію, серед них: артеріальна гіпертензія у $25(43,1 \%)$, ожиріння - у $16(27,6 \%)$, кісти контралатеральної нирки - у $7(12,1 \%)$, сечокам'яна хвороба - у $5(8,6 \%)$, цукровий діабет - у $2(3,4 \%)$, перенесений в анамнезі інфаркт міокарда - в $1(1,7 \%)$ хворого. Усі пацієнти - зі світлоклітинним типом НКР. Діагноз підтверджено за допомогою пункційної біопсії, виконаної до проведення ТТ та оперативного втручання.

Статистичну обробку отриманих результатів проводили за допомогою програмного забезпечення SPSS. Оцінку розподілу неперервних даних у групі виконували за побудовою діаграм розподілу, а також за критерієм Колмогорова - Смирнова. Описова статистика включала обчислення середнього значення зі стандартним відхиленням $(\mathrm{M} \pm \mathrm{SD})$ або медіани з 25-75-м процентилями (Ме [25\%; 75\%]). Порівняння кількісних показників проводили з використанням критерію Манна - Уїтні, якісних - критерію Пірсона. Статистично значущими відмінностями вважали вірогідності помилки 1 -го роду $<5 \%(\mathrm{p}<0,05)$.

\section{РЕЗУЛЬТАТИ}

Об’єктивну відповідь локалізованого НКР на проведення неоад'ювантної ТТ оцінювали на основі мультиспіральної комп'ютерної томографії (МСКТ) на одному і тому ж апараті з метою виключення похибки. При цьому даних про наявність регіонарного та віддаленого метастазування не виявлено в жодному дослідженні.

Частка регресії пухлини коливалася від 0 до $60 \%$ і в середньому становила 20,5 $\pm 14,3 \%$ (95\% ДІ 16,8-24,3). У більшості випадків - $50(86,4 \%)$ - після проведення неоад'ювантної ТТ розмір пухлини зменшився. Відсутність відповіді на проведення ТТ (0\% регресіі) відмічена у $8(13,8 \%)$ хворих.

Також проведено оцінку регресії пухлини за RECIST 1.1 за результатами неоад’ювантної ТT. Прогресія захворювання не була відмічена в жодному випадку. Більшість пацієнтів мали незначну позитивну відповідь на проведення TT за RECIST 1.1 (від 3 до 29\% регресії локалізованого НКР), яка досягалася в 44 (76,9\%) випадках і оцінена як стабілізація процесу. При цьому часткова відповідь за RECIST 1.1 відмічена в $14(24,1 \%)$ випадках і максимально сягала $60 \%$. На жаль, у жодному випадку не було констатовано повної відповіді локалізованого НКР на неоад'ювантну ТТ.

Проведення двох блоків неоад'ювантної ТТ у хворих на локалізований НКР дозволило достовірно (t-test; $\mathrm{p}<0,001)$ зменшити середній розмір пухлини нирки на 12,3 мм -

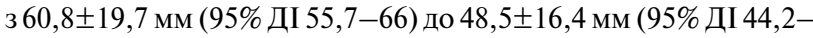
$52,8)$. Аналогічну різницю відмічено в збільшенні медіани об'єму функціонуючої паренхіми нирки на 21\% з 62 [57; 77] до 83 [70; 90] мм. У сумі це відіграло в ситуації локалізованого НКР ключову роль у виборі методу оперативного лікування на користь резекції нирки, яку виконали в $53(91,4 \%)$ випадках.

У подальшому нами проведено пошук взаємозв'язку між розмірами пухлини нирки до та після проведення неоад'ювантної ТТ за допомогою кореляційного аналізу Пірсона (рис. 1).
Як видно з рис. 1, проведений аналіз виявив достовірну кореляційну пряму залежність $(\mathrm{r}=0,77613 ; \mathrm{p}<0,001)$ розміру локалізованого НКР до проведення неоад'ювантної ТТ і розміру пухлини нирки після ії проведення. Враховуючи рівень регресії пухлини нирки під дією неоад'ювантної ТТ, ми побудували криву прогнозування розмірів НКР після проведення неоад'ювантної ТТ на основі вихідних розмірів пухлини за даними МСКТ. Наприклад: при вихідних розмірах НКР 100 мм прогнозований розмір пухлини після проведення 2 курсів неоад'ювантної терапії з 95\% вірогідністю буде в межах 67-80 мм.

Важливим аспектом дослідження ефективності неоад'ювантної ТТ у хворих на локалізований НКР є визначення можливої залежності рівня об'єктивної відповіді на лікування від інших факторів, що, на нашу думку, в подальшому дасть можливість прогнозування ефективності лікування.

Нами проведено аналіз можливої залежності рівня об'єктивної відповіді локалізованого НКР від розміру первинного вогнища в нирці (рис. 2).

Представлені на рис. 2 дані свідчать про відсутність залежності рівня об’єктивної відповіді пухлини на проведення неоад'ювантної ТТ від розміру локалізованого НКР. Так, при пухлині розміром 113 мм рівень об'єктивної відповіді становив 43\%, при цьому інша пухлина великих розмірів (93 мм) зовсім не дала відповіді на проведення неоад’ювантної ТТ (0\% регресії). Аналогічні розбіжності рівня об’єктивної відповіді відмічалися при пухлинах невеликих розмірів. В одному випадку пухлина розміром 34 мм дала рівень об'єктивної відповіді в 58\%, в іншому - при пухлині 36 мм досягнуто об'єктивної відповіді лише в $6 \%$.

У подальшому нами проведено оцінку залежності рівня відповіді від стадії захворювання за параметром T (TNM класифікації), яку представлено в таблиці.

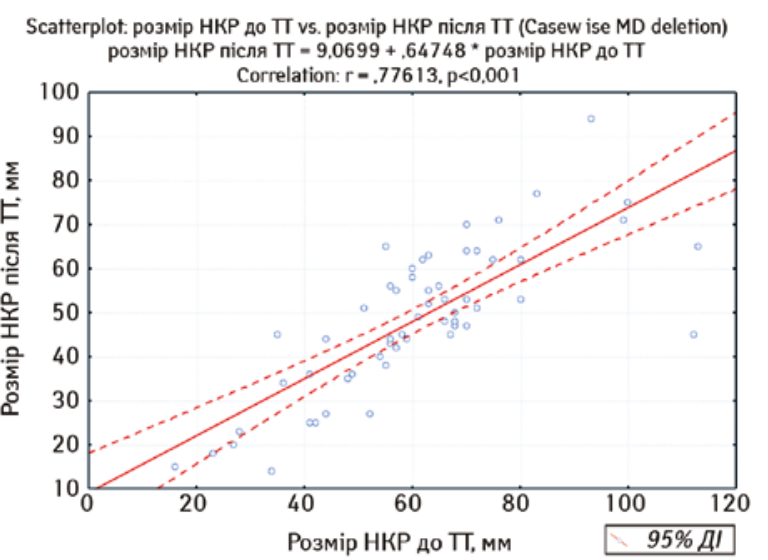

Рис. 1. Взаємозв'язок розміру локалізованого НКР до та після проведення неоад'ювантної ТТ, визначений за допомогою кореляційного аналізу Пірсона

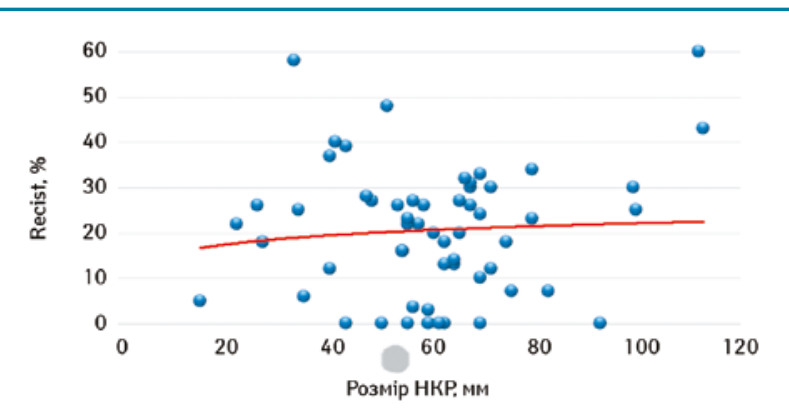

Рис. 2. Залежність рівня регресії локалізованого НКР від розмірів первинної пухлини нирки, $\mathrm{n}=58$ 
Таблиця. Залежність рівня регресії локалізованого НКР від стадії пухлини нирки, $\mathrm{n}=58$

\begin{tabular}{lcc}
\hline $\begin{array}{c}\text { T-стадія (за TNM } \\
\text { класифікацією) }\end{array}$ & $\begin{array}{c}\text { Регресія HKP, \% } \\
\mathbf{M} \pm \mathbf{S D}(\mathbf{9 5 \%} \text { ДI) }\end{array}$ & Статистична оцінка \\
\hline T1a, $n=7$ & $22,9 \pm 17,7(6,5-39,2)$ & ANOVA: \\
T1b, $n=35$ & $18,8 \pm 13,2(14,3-23,2)$ & $\eta^{2}=0,01 ;$ power $=0,1 ;$ \\
T2, $n=16$ & $22,3 \pm 16,3(13,6-30,9)$ & $p=0,72$ \\
\hline
\end{tabular}

Як видно з таблиці, не виявлено статистично значущої різниці у відсотку регресії первинної пухлини нирки залежно від стадії Т. Так, при розмірах пухлини до 4 см (Т1а стадія) середній

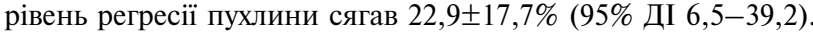
У підгрупі з розміром пухлини від 4 до 7 см (Т1b стадія) середній відсоток регресії пухлини був нижчим і становив $18,8 \pm 13,2 \%$ (95\% ДІ 14,3-23,2), а у підгрупі з розміром пухлини $>7$ см (Т2) середній відсоток регресії пухлини не відрізнявся від середніх

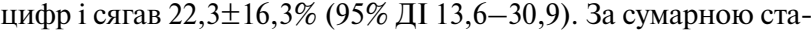
тистичною оцінкою, проведеною методом ANOVA, не виявлено впливу Т стадії НКР на відсоток регресії пухлини. Так, ефект впливу становив $\eta^{2}=0,01$ при потужності впливу 0,1 і не був достовірно значущим ( $\mathrm{p}=0,72)$. У подальшому нами проведено Post-hoc аналіз методом Newman - Keuls test (рис. 3).

Як видно з рис. 3, Newman - Keuls test засвідчив відсутність достовірної різниці між усіма підгрупами дослідження. Так, між T1a та T1b показник достовірності становив $\mathrm{p}=0,8$, між групами $\mathrm{T} 1 \mathrm{~b}$ та T2 $-\mathrm{p}=0,6$. Таким чином, ми не знайшли кореляційної залежності між розміром пухлини та ступенем регресії локалізованого НКР у відповідь на проведення неоад'ювантної ТТ.

\section{ОБГОВОРЕННЯ}

Представлені в нашій роботі результати дослідження ефективності проведення неоад'ювантної ТТ в лікуванні хворих на локалізований НКР виявилися доволі перспективними.

В основу принципу використання неоад'ювантної ТТ при НКР закладено концепцію підвищення безпеки процедури та покращення локорегіонарного контролю [11]. Використання комбінованого лікування НКР в такому вигляді дозволяє зменшити розмір пухлини нирки з подальшою вищою вірогідністю проведення органозберігаючого лікування, в тому числі у випадках імперативних показань до органозбереження та при анатомічно складних пухлинах нирки. Зменшення об'єму пухлини в лікуванні локалізованого НКР спрямоване перш за все на покращення функціональних результатів та збереження відсотка функціонуючої паренхіми нирки [12].

Використання неоад'ювантного лікування в онкології направлене на зменшення кількості побічних проявів та покращення переносимості обраної терапії завдяки наявності двох функціонуючих нирок при максимальному об'ємі функціонуючої паренхіми, що значно підвищує дезінтоксикаційні можливості організму в цілому [8, 9].

Проведений в нашій роботі аналіз взаємозв'язку між розмірами пухлини нирки до та після неоад'ювантної ТТ за допомогою кореляційного аналізу Пірсона виявив достовірну кореляційну пряму залежність $(\mathrm{r}=0,77613 ; \mathrm{p}<0,001)$, на основі

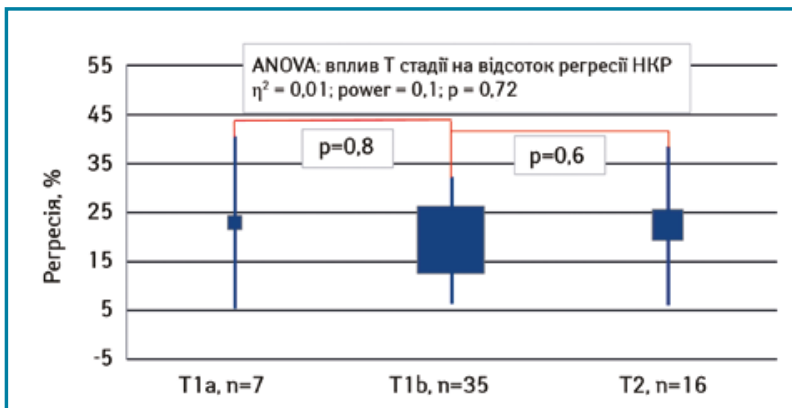

Рис. 3. Залежність рівня регресії локалізованого НКР від стадії пухлини нирки, $\mathrm{n}=58$ чого було побудовано криву прогнозування розмірів НКР після проведення неоад'ювантної ТТ з урахуванням вихідних розмірів пухлини за даними МСКТ (див. рис. 1). Такий підхід дозволяє прогнозувати, чи достатнім буде рівень регресії локалізованого НКР для подальшого проведення органозберігаючого оперативного лікування. 3 огляду на це може бути зроблено висновок про доцільність виконання органозберігаючої операції, що дозволить (при несприятливому результаті) зекономити кошти на придбання препаратів, запобігти можливим побічним проявам лікування таргетними препаратами та скоротити час до проведення операції, що може вплинути на онкологічну ефективність лікування та якість життя пацієнтів.

Зв'язок між розміром НКР та ступенем регресії під впливом неоад'ювантної ТТ описали в своїй роботі В.К. Kroon та співавтори [13], які на основі лікування 78 хворих на метастатичний НКР різними препаратами групи інгібіторів тирозинкінази виявили пряму кореляційну залежність. Вони зробили висновок, що чим менший розмір первинного НКР, тим більша ймовірність і ефективніша регресія пухлини. Однак отримані в нашій роботі результати не виявили залежності рівня об'єктивної відповіді пухлини на проведення неоад’ювантної ТТ від розміру локалізованого НКР.

Наведені в нашій роботі дані свідчать про клінічну ефективність проведення неоад'ювантної ТТ у пацієнтів із локалізованим НКР з метою зменшення розмірів пухлини нирки та подальшої органозберігаючої тактики лікування, що дозволяє значно знизити вірогідність розвитку хронічної ниркової недостатності, збільшити тривалість та підвищити якість життя пацієнтів внаслідок зниження інвалідизації.

\section{вИСНОВКИ}

Проведення неоад'ювантної ТТ у хворих на локалізований НКР зумовило достовірну регресію пухлини у середньому на $20,5 \pm 14,3 \%$ при розмірі первинної пухлини $60,7 \pm 19,8$ мм, що забезпечило можливість проведення органозберігаючого оперативного лікування у 91,4\% випадках.

Розроблено систему прогнозування рівня регресії пухлини внаслідок проведення неоад'ювантної ТТ, що дозволяє з 95\% вірогідністю визначити ефективність зменшення ії розмірів та доцільність такого лікування.

\section{СПИСОК ВИКОРИСТАНОÏ ЛІТЕРАТУРИ}

1. Ferlay, J., Steliarova-Foucher, E., Lortet-Tieulent, J., Rosso, S., Coebergh, J. W., Comber, H., ...Bray F. (2012). Cancer incidence and mortality patterns in Europe: estimates for 40 countries in 2012. European Journal of Cancer, 49(6), 1374-1403. doi: 10.1016/j.ejca.2012.12.027.

2. Ljungberg, B., Hanbury, D. C., Kuczyk, M. A., Merseburger, A. S., Mulders, P. F. A., Patard, J-J., \&Sinescu, I. C. (2007). EAU Guidelines on Renal Cell Carcinoma2007 ISBN 97890-70244-59-0. European Association of Urology. Retrieved from https://uroweb.org/wpcontent/ uploads/EAU-Guidelines-Renal-Cell-Carcinoma-2007.pdf.

3. Smith, D. H., Thorp, M. L., Gurwitz, J. H., McManus, D. D., Goldberg, R. J., Allen, L. A. ...Go, A. S. (2013). Chronic kidney disease and outcomes in heart failure with preserved versus reduced ejection fraction: the Cardiovascular Research Network PRESERVE Study. Circulation Cardiovascular Quality and Outcomes, 6(3), 333-342. PRESERVE Study. Circulation Cardiovascular
doi: 10.1161 /CIRCOUTCOMES.113.000221.

4. NCCN Guidelines Version 2.2019. Kidney Cancer. Retrieved from https://www.nccn.org/professionals/physician_gls/pdf/kidney.pdf.

5. Ljungberg, B., Albiges, L., Bensalah, K., Bex, A., Giles, R.H., Hora, M., Volpe, A. (2018). Renal Cell Carcinoma. European Association of Urology. Retrieved from https://uroweb.org/guideline/renal-cell-carcinoma.

6. Go, A. S., Chertow, G. M., Fan, D., McCulloch, C. E., \& Hsu, C. Y. (2004). Chronic kidney disease and the risks of death, cardiovascular events, and hospitalization. The New England Journal of Medicine, 351(13), 1296-1305. doi:10.1056/NEJMoa041031.

7. Herzog, C. A., Asinger, R. W., Berger, A. K., Charytan, D. M., Diez, J., Hart, R. G.,

Ritz, E. (2011). Cardiovascular disease in chronic kidney disease. A clinical update from Kidney Disease: Improving Global Outcomes (KDIGO). Kidney International, 80(6), 572-586. doi: 10.1038/ki.2011.223.

8. Silberstein, J. L., Millard, F., Mehrazin, R., Kopp, R., Bazzi, W., DiBlasio, C. J., ... Derweesh, I. H. (2010). Feasibility and efficacy of neoadjuvant sunitinib before nephron-sparing surgery. BJU International, 106(9), 1270-1276. doi: 10.1111/j. 1464-410X.2010.09357.

9. Rini, B. I., Plimack, E. R., Takagi, T., Elson, P., Wood, L. S., Dreicer, R., ...Campbell, S. C. (2015). A phase II study of pazopanib in patients with localized renal cell carcinoma to optimize preservation of renal parenchyma. Journal of Urology, 194(2), 297-303. doi: 10.1016/j.juro.2015.03.096.

10. Стаховський, Е. О., Войленко, О. А., Вітрук, Ю. В., \& Стаховський, О. Е. (2015). Застосування нефрометрії для вибору тактики лікування хворих з приводу нирковоклітинного раку. Клінічна хірургія, 3, 55-60.

11. Bindayi, A., Hamilton, Z. A., McDonald, M. L., Yim, K., Millard, F., McKay, R. R., Derweesh, I. H. (2018). Neoadjuvant therapy for localized and locally advanced renal cell carcinoma. Urologic Oncology, 36(1), 31-37. doi: 10.1016/j.urolonc.2017.07.015. 
12. Lane, B. R., Derweesh, I. H., Kim, H. L., O'Malley, R., Klink, J., Ercole, C. E., ...Campbell, S. C. (2015). Presurgical sunitinib reduces tumor size and may facilitate partial nephrectomy in patients with renal cell carcinoma. Urologic Oncology, 33(3), 112e15-e21. doi: 10.1016/j.urolonc.2014.11.009.

13. Kroon, B.K., de Bruijn, R., Prevoo, W., Horenblas, S., Powles, T., \& Bex, A. (2013) Probability of downsizing primary tumors of renal cell carcinoma by targeted therapies is related to size at presentation. Urology, 81(1), 111-115. doi: 10.1016/j.urology.2012.09.014.

\section{Прогнозирование эффективности}

неоадъювантной таргетной терапии у больных локализованным почечно-клеточным раком

\section{O.A. Войленко}

Национальный институт рака, Киев

Резюме. Цель - определить прогностические критерии эффективности проведения неоадъювантной таргетной терапии (ТТ) в лечении больных локализованным почечноклеточным раком (ПКР). Объект и методы. 58 пациентов с локализованным ПКР, которым в период с 2017 по 2018 г. проведено 2 блока неоадъювантной ТТ с определением объективного ответа на лечение и последующим оперативным вмешательством. Результаты. Доля регрессии опухоли после

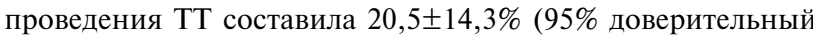
интервал (ДИ) 16,8-24,3). Размер ПКР уменьшился в среднем на 12,3 мм - с 60,8 $\pm 19,7$ мм (95\% ДИ 55,7-66) до 48,5 $\pm 16,4$ мм (95\% ДИ 44,2-52,8) (t-test; $<<0,001)$, что позволило в 53 случаях $(91,4 \%)$ провести резекцию почки. С помощью корреляционного анализа Пирсона выявлена достоверная корреляционная прямая зависимость $(\mathrm{r}=0,77613 ; \mathrm{p}<0,001)$ размера ПКР после проведения неоадъювантной ТТ от размера локализованного ПКР до ее выполнения. Установлено отсутствие зависимости уровня объективного ответа опухоли на проведение неоадъювантной ТТ от размера локализованного ПКР. Выводы. Разработанная система прогнозирования уровня регрессии локализованного ПКР в результате проведения неоадъювантной ТТ позволяет с 95\% вероятностью определить эффективность уменьшения размеров опухоли и целесообразность такого лечения.

Ключевые слова: почечно-клеточный рак; неоадъювантная таргетная терапия.
Prediction of the effectiveness of neoadjuvant targeted therapy in patients with localized renal cell carcinoma

O.A. Voylenko

National Cancer Institute, Kyiv

Summary. Objective. To determine prognostic criteria of neoadjuvant targeted therapy (TT) efficacy in the treatment of patients with localized renal cell carcinoma (RCC). Materials and methods. 58 patients with localized RCC, who underwent 2 cycles of neoadjuvant TT in the period from 2017 to 2018 with evaluation of objective response level and subsequent surgical treatment outcomes. Results. Average regression after TT was $20.5 \pm 14.3 \%$ (95\% confidence interval (CI) 16.8-24.3). The size of the RCC decreased in average up to $12.3 \mathrm{~mm}$ - from $60.8 \pm 19.7 \mathrm{~mm}(95 \%$ CI $55.7-66)$ to $48.5 \pm 16.4 \mathrm{~mm}(95 \%$ CI 44.2 $\pm 52,8)$ (t-test; $\mathrm{p}<0,001)$, which allowed to perform partial nephrectomy in 53 cases $(91,4 \%)$. The Pearson's correlative analysis showed a reliable dependence $(r=0,77613 ; p<0,001)$ of localized RCC size after neoadjuvant treatment from prior tumor size before neoadjuvant treatment. There was no dependence between objective tumor response level and tumor size prior to TT. Conclusion. A system for predicting levels of localized RCC regression after TT was developed, which provides a 95\% probability of determining efficacy in reducing tumor size and feasibility of such treatment.

Key words: renal cell carcinoma; neoadjuvant targeted therapy.

Aдреса:

Войленко Олег Анатолійович

03022, Київ, вул. Ломоносова, 33/43

Національний інститут раку

E-mail:voilenko@rambler.ru

Correspondence: Voylenko Oleg 33/43 Lomonosova Str., Kyiv 03022 National Cancer Institute E-mail:voilenko@rambler.ru 